\section{The Concept Of Motive And Its Interpretations On Literature}

\author{
Kuchkarov Oybek Abdumansurovich \\ Doctoral Student \\ Andijan State University, Uzbekistan
}

\begin{abstract}
G OPEN ACCESS
The American Journal of Social Science And Education Innovations JULY 2020

Page No.: 145-152

Volume-II Issue-VII

PUBLISHED: 30 JULY 2020 www.usajournalshub.com/inde x.php/tajssei

Copyright: Original content from this work may be used under the terms of the Creative Commons Attribution 4.0 licence.
\end{abstract}

\title{
Abstract
}

This article discusses the concept of motive and its interpretations in literature, genesis, functions, about place in the poetic system. The article analyzes the views of some Western scholars that have caused controversy about the motive and makes well-founded comments.

Keywords: motive, plot, schematic formula, dichotomous concept, invariant, fable.

\section{Introduction}

The term "motive" came to literary criticism from musicology. In musicology, a "motive" is a rhythmically formed part of a melody that combines several notes. On the basis of similarity, the smallest part of a literary work began to be understood in literary criticism. However, if we take into account the interpretations of the term "motive" in the literature, the definitions of the concept, the units that are interpreted as motives in research, we can be sure that the definitions of this term are different. That is why we must first determine in our work how we understand this term. To this end, in this article we will 
briefly review the existing views in the literature on motives.

The first meaning of the motive given in the "Russian-Uzbek Glossary of Literary Terms" is as follows: "It's one of the rings in the plot. In the same sense, the term motive is used in folklore, especially in the study of major epic genres such as epics and fairy tales "[1.190]. it is said. The dictionary article incorporates the idea that the term is mainly specific to folklore, with examples based on Russian and Uzbek folklore. The authors briefly dwell on the second meaning of the term, saying, "In literature, the term motive is applied to an additional subject or ideological line that serves to complement the main theme and idea of the work"[1.191]. According to this interpretation, the motive is a member of the content, in other words, the term is used as a synonym for the second term in the "main theme" series. That is, in the dictionary, the authors tried to explain the term motif as clearly as possible. However, many sources on literary theory emphasize the ambiguous nature of the term motive. For example, in the Literary Dictionary, the motive is described as follows: "MOTIVE (lot. moveo - move) - a term derived from musicology. $M$. in music the work is considered the smallest unit of form, and the work develops on the basis of its exact repetition (as well as the modification or introduction of contradictory M.s.). In literature M. The term is used in different senses. In particular, in the incidental works M. plot scheme (e.g., the protagonist is tied up, any girl helps him; stepmother and a pious righteous girl; the protagonist rises from an orphan to a high rank; the protagonist does not know his father, meets him in an emergency, etc.) or something (e.g., a mirror, a tumor), a situation (e.g., dreaming, talking to a ghost, walking anonymously), an image (a wise minister, a loyal friend, an adversary), and so on. One of the important aspects inherent in M. is the possession of a certain stability. In other words, the Ms are taken in a semi-finished form: the existing Ms are not exactly, but are interpreted in different variants, depending on the writer's artistic imagination and creative intention, while preserving the core. [2.180]. This definition states that a motive is a plot scheme, but that an object, situation, or image depicted in a work of art can also be called a "motive". Therefore, when the dictionary later classifies the types of artistic images, the concept of "motive image" is given: "Motive (motive image) is an image that has gained a certain stability in terms of form and content, and reflects their creative aspirations by being 
repeated in the works of one or more artists."[2.180].

\section{The Main Findings And Results}

As we can see, both definitions of "motive" and "motive image" in the Literary Dictionary emphasize repetition. Indeed, the same feature represents the most important aspect of the motive, making it one of the typological concepts. That is, in the same way, the concept of motive allows a clear idea of the general aspects of the art world of a particular artist or artists who lived in a particular period. Thus, it can be concluded from the above that the concept of "motive" is a very important scientific category, both in the study of individual works of art, and in the study of the literature of a particular period.

The problem of motive has not been studied consistently in Uzbek literature. If some research in the field of folklore does not address issues such as the genesis, functions, role of individual motives in the poetic system, there is almost no theoretical work on the problem of motives. Perhaps this is the reason, or whether the motive is known to all, something that is known to everyone, the research goes directly to the topic, and even in the beginning the theoretical information about the motive is not given in the form of a review. That is why we have to rely more on the work of foreign scientists in our research.

In fact, the term "motive" appeared in European musicology in the XVIII century, and soon after that it was adopted in literary criticism. In any case, the fact that the term motive was applied to literature in the correspondence between Goethe and Schiller in 1797-1798 gives grounds for such a calculation[3.436]. In the early nineteenth century, theorists of German Romantic literature began to use the term more actively. Nevertheless, the term has been used very actively in literature since the late 19th century. During this period, the term "motive" meant a concept related to the plot, and attempts were made to understand and explain it in the example of more folklore works. The study of the motive in relation to the plot and as an important scientific category for comparative analysis was initiated by the Russian scientist A.N Veselovsky. In his work, Poetics of Plot, the motive is interpreted as the simplest, indivisible unit of narration, a schematic formula underlying the plot. The scientist writes: "By motive I mean a formula that in the early days of human society answers the questions that nature posed to man 
everywhere, or seals impressions that appear to be particularly bright, important, or repetitive from reality"[4.301] . A.N Veselovsky called the motive "one-syllable figurative schematism" because he saw it as an integral part of the plot. According to him, such examples as "the theft of the sun or fire", "the clouds do not rain or the spring water dries up", "the lily torments the beauty" can be examples of motives. Looking at the issue from the point of view of historical poetics, the scholar believes that plot formulas such as the above have emerged independently of each other in different tribes. That is, he argues that in this case there is no phenomenon of assimilation, the generality of the living conditions and the psyche formed under their influence is understood as the main factor of this similarity [4. 301]. From this it can be seen that A.N Veselovsky recognized the similarities observed in the motives as a typological commonality. Plots grow from these motives. The scientist explains this as follows: "the simplest motive formula $a+b$ ". While the first (a) part of the formula is "the evil old woman's dislike of beauty", the second (b) part is "the burden of a life-threatening task". Importantly, both parts of this formula can change, especially since part b of it tends to expand. For example, "a task can be two, three (favorite number) and more; there will be a meeting in the path of the hero, such meetings may also be multiple. Thus, the motive becomes the plot ..." [4.301] When talking about motives, A.N Veselovsky emphasizes the nature of their repetition. It should be noted that the work "Poetics of the plots" quoted above was created in the last period of the scientist's career. In fact, he had noticed the repetitive nature of the motif in his early works [5.32]. Since he developed his doctrine of motives on the basis of myths and folklore, A.N Veselovsky argued that motives are historically stable and can be repeated infinitely (in later periods). The same feature of repetition is central to all existing scientific concepts about motive.

When A.N. Veselovsky speaks about the feature of indivisibility, when he calls the motif "one-syllable figurative schematism", he means its semantic side, that is, as an image it has a meaning with a whole aesthetic value. This understanding of the motive was referred to in literature as the "semantic concept" and was later developed in the work of A.L. Bem and O.M. Freidenberg [6.17].

By the end of the 1920s, the semantic concept developed by A.N. Veselovsky was 
criticized by V.Ya. Propp. In contrast to AN Veselovsky, who considered the semantic integrity of the image as the basis of indivisibility, V.Ya. Propp took the concept of "logical integrity" as the main criterion. V.Ya. Propp writes that the motives cited by his predecessor as an example to prove his point are also fragmented: "take the motive of "the dragon stole the king's daughter." This motive is divided into 4 elements, each of which can be varied individually. The dragon can easily be replaced by Koshchey, a hurricane, a devil, a falcon or a witch" [7.22]. After criticizing the concept of motive on the basis of the criterion of logical integrity, Propp completely abandons it and instead introduces the concept of "participant person function" as a small unit of narration. However, in motivational studies, it is noted that V. Propp's attempt to deny the views of A. Veselovsky actually led to the opposite result.

For example, according to S.G. Shalygina, the concept of "participant personality function" introduced by V.Ya. Propp into scientific circulation did not replace the concept of motive, but deepened its semantic interpretation. Indeed, from the point of view of motive semantics and the plot in general, the function envisaged by $\mathrm{V}$. Propp is only one of the semantic components of the motive, in essence, it expresses a generalized meaning cut from many fabulous variants of the motive. From this point of view, it turns out that V.Ya. Propp has consistently carried out the process of generalization of motives [8.250]. In expressing these views, the researcher relies on the following ideas of I. Silantev: "function is a general sema, or a set of general semaphores that occupy a central and invariant position in the structure of the variable meaning of the motive. Therefore, even an ore member of a motive, as a semantic invariant, cannot replace a function motif, just as a part (even when it is central) cannot replace a whole" [6.27].

In view of the above, the leading experts in the field of motivation of the modern age prefer the concepts of "motive" and "function of the participant". In particular, one of the world's leading experts in the field, E.M Meletinsky, says: "Most of the function options listed by Propp are typical motives" [9.115]. B.N Putilov and V.V Ivanov also support the fact that there is a complementary relationship between these two concepts, not an alternative to each other. [10.310]. Most importantly, V.Ya. Propp himself returns to the concept of motive in his later work, The Morphology of Magic Tales. Experts note that 
V.Ya. Propp in this work methodologically followed the path revealed by A.N. Veseslovsky, followed him [11.126].

It is clear from the above that there are different views on the issue of motives in literature. In the 1920s, there were experts who rejected the notion of "motive" altogether, viewing it as an abstraction that was not necessary for literature or did not exist at all, and was intended to be studied. In particular, L.A. Bem, who discovered the invariant origin in the structure of the motive, connects it directly with the semantic integrity of the motive, and the variants with the content of the concrete work. This is the basis for him to deny the literary existence of the motive, to conclude that "motives are fictions formed by abstracting from concrete content" [8.252]. Later, B.I. Yarkho denied the status of the motive as a unit of narration described by A.N. Veselovsky. According to him, the motive is actually a division of the plot, but its boundaries are determined voluntarily by the researcher himself. Therefore, since the boundaries of a motive are determined subjectively, it cannot be accepted as a specific unit. In addition, B.I. Yarkho also denies the semantic status of the motive, because "a single set of events can be called both "Eugene and Lensky's quarrel" and "the skeptic's clash with the enthusiast." Such views lead the scientist to completely deny the literary existence of the motive: "Obviously, the motive is not a real part of the plot, but a working term that serves to compare the plots" [12.221].

Along with the tendency to deny the existence of the motive, its dualistic nature began to be understood in the literature of this period. That is, in the research on the subject created during this period, the motive began to be understood, on the one hand, as a unit of ARTISTIC LANGUAGE with its own generalized meaning, on the other hand, as a unit of ARTISTIC SPEECH with specific semantics.

The dichotomous (two-sided) nature of the motive is determined by the fact that it contains semantic invariant and fable variants that appear in a particular work. In his book The Word Artist's Workshop (1923), AI Beletsky distinguishes between the concepts of "schematic motive" and "real motive" for the first time. The scientist believes that the first of these is connected with the "invariant scheme" and the second with the plot of a particular work. This can be clearly seen from the examples he gives: The real image of 
the main motive in the "Caucasian captive" is expressed as "a Circassian girl loves a Russian captive", while its semantic invariant is in the form "a foreign girl loves a captive". The dichotomous concept, discovered by AI Beletsky and practically developed by V. Propp in the work "Fairy Morphology", was fully formed in the works of a number of scientists such as L. Dolejal, A. Dandes, L. Parpulova, N.G Chernyaeva.

\section{Conclusion}

Although the thematic approach to the motive is theoretically described in the works of V.B Tomashevsky, B.V Shklovsky, its roots are already in A.N Veselovsky. Explaining the motif through the theme, V.B Tomashevsky suggests that there is a theme for the whole work and for each part: "Going by dividing the work into thematic parts, we finally reach its indivisible parts, the smallest pieces of thematic material ... The theme of the integral part of the work is called the motive. Essentially - each sentence has its own motive" [13.182]. In B. Tomashevsky's interpretation, the motive is a concept derived from the subject, which serves as an auxiliary function within the subject: it connects the fable and the plot and serves to determine the relationship between them. For this approach, the scientist does not deny the concept of "indivisibility" in the interpretation of A.N Veselovsky. The reason for this is that he called the "thematic unity motif found in various works in comparative study ... These motifs pass from one plot device to another as a whole. It is not interesting for comparative poetics to be able to divide them into even smaller motives" [13.182]. That is, B. Tomashevsky follows the path of compromise: he acknowledges the need for the principle of indivisibility in comparative study, ignoring the fact that it does not correspond to the thematic concept he puts forward. V. Shklovsky's understanding of the motive is essentially thematic, but from the point of view of $B$. Tomashevsky it is noticeable, even contradictory in terms of its relation to the fable and plot. In B. Tomashevsky's interpretation, the motif is the thematic "brick" of the plot, while in V. Shklovsky's interpretation, the motive is the semantic "brick" of the plot, that is, above the fable. Like V. Shklovsky, A.P Skaftymov connects the motive to the plot, more precisely, to the psychological theme generalized by the plot of the work. Accordingly, he also explains the indivisibility of the motive by linking it to the holistic 
psychological nature of the character (such as the "motive of guilt", the "motive of jealous selfishness") [14.33].

Above we have taken a look at the history of the main scientific directions in the study of motives - semantic, morphological, dichotomous, thematic approaches. Based on the achievements of these scientific directions and the development of ideas, the science of motivation (motivation) was formed, and the in-depth study of the issue from various aspects continues. S.Thompson, A.Dandes, A.Greymas, V.Kaiser, L.Parpulova, L.Dolejal, J.Jenett, E.M.Meletinsky, B.M.Gasparov, A.M. The scientific research of many scientists, such as K. Zholkovsky, N.G Chernyaeva, B.N Putilov, N.D Tamarchenko, V.I Tyupa, enriched the theory of motives. We will limit ourselves to what has been said so far, with the intention of dwelling on this later in a separate article.

\section{References}

1. Khatamov N; Sarimsoqov B. Russian-Uzbek Explanatory Dictionary of Literary Terms.Tashkent:Teacher, 1979. - p.190.

2. Quronov D., Mamajonov Z., Sheralieva M. Literary Dictionary. Tashkent: Akademnashr, 2010. - p.180.

3. Goethe I.V; Schiller F. Correspondence: in 2 volumes.Vol. 1. Moscow: Art, 1998. - p. 436

4. Veselovsky A.N. Historical poetics. Moscow: Higher school, 1989. - p.301

5. Veselovsky A.N. On the method and tasks of the history of literature as a science. // Veselovsky A.N. Historical poetics. Moscow: Higher school, 1989.- p. 32-41

6. I.V. Silantyev Poetics of motive. Moscow: Languages of Slavic culture, 2004. - pp.17-20 7. Prop V. Morphology of a fairy tale. L: Academia, 1928. - p. 22

8. Shalygina S.G. The concept of "motive" and its interpretation in the theory of literature and music // Socio-economic phenomena and processes. 2001. No. 1 (035) . - pp. 250254

9. Meletinsky E.M. Semantic organization of mythological narration and the problem of creating a semiotic index of motives and plots // Uchen.zap. Tartu State un-that. Issue 635. Tartu: 1983.- p. 115-125

10. Putilov B.N. Veselovsky and the problems of folklore motive // Heritage of Alexander Veselovsky. Research and materials. SPb, 1992.- p. 74-85.

11. Ivanov V.V. From the past of semiotics, structural linguistics and poetics // Essays on the history of informatics in Russia.Novosibirsk: 1998. - pp. 310-340

12. Meletinsky E.M. Poetics of Myth. Moscow: 1976. - p. 126

13. Yarkho B.I. Methodology of Exact Literary Studies (outline outline). The context is 1983. Moscow: 1984. - pp. 221-222

14. Tomashevsky B.V. Literature theory. Poetics. Moscow: Aspect press, 1996. - p. 182

15. Skaftmov A.P. Moral searches of Russian writers. Moscow: Fiction, 1972. - p. 33-35 